\title{
Individual Animal Selection Has the Potential to Improve Uniformity of Grazing on Foothill Rangeland
}

\author{
Derek W. Bailey, ${ }^{1}$ Harv C. VanWagoner, ${ }^{2}$ and Robin Weinmeister ${ }^{3}$ \\ Authors are ${ }^{1}$ Associate Professor, Department of Animal and Range Sciences, New Mexico State University, \\ Las Cruces, NM 88003; and ${ }^{2}$ Research Associate and ${ }^{3}$ Research Technician, Northern Agricultural Research Center, \\ Montana State University, Havre, MT 59501.
}

\begin{abstract}
Uneven grazing distribution is a concern in rugged topography, because resources may be adversely impacted if livestock concentrate in gentle terrain near water. A study was conducted to determine if removing cattle with undesirable distribution patterns has the potential to increase uniformity of grazing. Before the study, 2 herds of cattle were observed by horseback observers during early mornings to establish terrain use patterns of individual animals. Cows were ranked on slope use and observed vertical and horizontal distance to water. Based on these rankings, cows were assigned to 1 of 2 treatments, hill climbers (observed on steeper slopes and farther from water) or bottom dwellers (used gentler slopes near water). Hill climber and bottom dweller cows grazed similar, but separate, pastures at 2 ranches during the 3 -year study for a total of 8 comparisons. Based on a normalized and integrated index of terrain use from visual observations, hill climber cows used steeper and more distant areas from water $(P=0.06)$ than bottom dwellers. Hill climber cows tracked by global positioning system collars used steeper and more distant areas from water than bottom dwellers $(P \leq 0.09)$ during the first 4 weeks of the 6 weeks that pastures were grazed based on a normalized index of terrain use. Forage utilization was more uniform $(P<0.05)$ across slopes and varying horizontal distances to water in pastures grazed by hill climbers than by bottom dwellers. Stubble heights in riparian and coulee bottom areas were higher $(P=0.01)$ when grazed by hill climber cows $(13.3 \mathrm{~cm})$ than by bottom dwellers $(8.1 \mathrm{~cm})$. This study demonstrates that cattle with divergent grazing patterns when observed in the same pasture continue to use different terrain when separated, and it suggests that individual animal selection has the potential to increase uniformity of grazing.
\end{abstract}

\section{Resumen}

La distribución no uniforme del apacentamiento es un problema en terrenos de topografía rugosa porque los recursos pueden ser afectados adversamente si el ganado se concentra en los terrenos planos cercanos del agua. Se condujo un estudio para determinar si la remoción del ganado con patrones de distribución indeseable tiene potencial para incrementar la uniformidad del apacentamiento. Previo al estudio, dos hatos de ganado se observaron temprano en la mañana con observadores a caballo para establecer los patrones de uso del terreno de animales individuales. Las vacas se clasificaron de acuerdo con el uso de la pendiente del terreno y la distancias observadas vertical y horizontal con respecto a la distancia del agua. Basados en esta clasificación, las vacas fueron asignadas a uno de dos tratamientos: 1 ) trepadoras de montaña (las observadas en pendientes pronunciadas y lejos del agua) y 2) moradoras del las partes bajas (vacas usuarias de pendientes suaves cercanas del agua). Las trepadoras y las moradoras de las partes bajas apacentaron en forma similar, pero separadas, en potreros en dos ranchos durante los tres años del estudio, para un total de 8 comparaciones. Basados en un índice normalizado e integrado del uso del terreno obtenido de observaciones visuales, determinamos que las vacas trepadoras usaron áreas con mayor pendiente y mas lejanas del agua $(P=$ 0.06) que las moradoras de las partes bajas. Durante las primeras 4 semanas de las 6 que los potreros fueron apacentados, las vacas trepadoras, rastreadas con collares con Sistema de Posicionamiento Global (GPS), usaron áreas con más pendiente y más distantes del agua que las vacas moradoras de las partes bajas $(P \leq .09)$, esto se determinó en base a un índice normalizado de uso del terreno. La utilización del forraje fue más uniforme $(P<0.05)$ a través de las pendientes y variando horizontalmente las distancias al agua en potreros apacentados por las vacas trepadoras de montaña que en las moradoras de las partes bajas. Las alturas del rastrojo de las áreas ribereñas y valles fueron mayores $(P=0.01)$ cuando se pastorearon por la vacas trepadoras de montaña $(13.3 \mathrm{~cm})$ que por las moradoras de las partes bajas $(8.1 \mathrm{~cm})$. Este estudio demuestra que el ganado con patrones divergentes de apacentamiento, cuando es observado en el mismo potrero, mantiene un uso diferente del terreno que cuando son separados y sugiere que la selección individual del animal tiene potencial para incrementar la uniformidad del apacentamiento.

Key Words: beef cattle, behavior, distribution, global positioning system

Research was funded in part by the US Dept of Agriculture Western Region Sustainable Agriculture Research and Education program and the US Dept of Agriculture-National Research Initiative Competitive Grants Program Award 9703712.

Correspondence: Derek W. Bailey, Dept of Animal and Range Sciences, New Mexico State University, PO Box 30003, MSC 3-I, Las Cruces, NM 88003-8003. Email: dwbailey@nmsu.edu

Manuscript received 12 December 2004; manuscript accepted 5 April 2006.

\section{INTRODUCTION}

Livestock grazing distribution is a critical component of sustainable rangeland management. Many concerns about livestock on grazed watersheds are the result of uneven distribution patterns (Bailey et al. 1996). A primary goal of ranchers and 
Table 1. Area and topographic information for the 6 pastures used in the study.

\begin{tabular}{|c|c|c|c|c|c|c|}
\hline & \multicolumn{4}{|c|}{ Thackeray Ranch } & \multicolumn{2}{|c|}{ Ross Ranch } \\
\hline & Back East & Back West & Rakes East & Rakes West & Blackwood North & Blackwood South \\
\hline Area, ha & 176 & 161 & 81 & 78 & 149 & 150 \\
\hline Range in slope, degrees & $0.1-48.8$ & $0.3-45.2$ & $0-51.4$ & $0.2-36.1$ & $0-27.0$ & $0-24.0$ \\
\hline Mean slope, degrees & 15.4 & 15.0 & 12.4 & 12.4 & 8.2 & 9.5 \\
\hline Range in elevation, $\mathrm{m}$ & $1186-1398$ & $1222-1398$ & $1152-1285$ & $1180-1293$ & $1104-1291$ & $1082-1290$ \\
\hline Mean elevation, m & 1260 & 1297 & 1203 & 1231 & 1166 & 1158 \\
\hline
\end{tabular}

land managers is to increase uniformity of grazing (DelCurto et al. 1999). Cattle often congregate in portions of extensive pastures and graze forage in these areas to excessive levels while other areas of the pastures receive little use (Pinchak et al. 1991). For example, cattle often prefer riparian areas and spend a disproportionate amount of time in these areas as compared to uplands (Smith et al. 1992). Concentrated grazing, especially in riparian zones, may reduce vegetative cover and stream bank stability as well as increase soil erosion (Kauffman et al. 1983; Blackburn 1984). If cattle spend more time grazing upland slopes farther from water, condition and function of riparian areas can be improved and wildlife habitat can be managed more effectively. The problem is determining the most efficient and cost-effective method to modify grazing patterns and prevent animals from overusing preferred areas within pastures (Bailey 2004).

Selecting cattle with desirable grazing patterns and culling cattle with undesirable grazing patterns has been suggested as a tool for improving distribution (Roath and Krueger 1982; Howery et al. 1996; Bailey et al. 1998). Research conducted in southern Idaho by Howery et al. (1996) showed that cattle maintained certain home ranges, some grazing primarily uplands and others grazing meadows and riparian areas. Thus, removing animals that concentrate in overused areas and selecting animals that travel farther from water and up steeper slopes has the potential to improve livestock grazing distribution. In contrast, Mosley (1999) speculates that selection may not be effective. After cattle with undesirable grazing patterns are removed, other animals may move in and "fill in the vacuum." The objective of this study was to determine if removing cattle with undesirable distribution patterns has the potential to increase uniformity of grazing in foothill rangelands. We hypothesized that cattle previously observed on rugged terrain far from water would continue to graze in similar areas when cattle observed on gentle slopes near water were placed in a separate pasture. We also hypothesized that forage utilization would be more strongly affected by slope and horizontal and vertical distance to water in pastures grazed by cattle with undesirable grazing patterns than in pastures grazed by animals with more desirable grazing patterns.

\section{METHODS}

\section{Study Areas}

Research was conducted at the Thackeray Ranch (lat $48^{\circ} 21^{\prime} 42^{\prime \prime} \mathrm{N}$, long $\left.109^{\circ} 35^{\prime} 46^{\prime \prime} \mathrm{W}\right)$, part of the Montana Agricultural Experiment Station, and at the Ross Ranch (lat $48^{\circ} 21^{\prime} 20^{\prime \prime} \mathrm{N}$, long $\left.109^{\circ} 30^{\prime} 29^{\prime \prime} \mathrm{W}\right)$, a cooperating private ranch.
Both study sites are located in the Bear's Paw Mountains about $25 \mathrm{~km}$ south of Havre, Montana, and $5 \mathrm{~km}$ from each other. Topography at both sites includes steep and gentle slopes. Lower elevations with gentle slopes were dominated by Kentucky bluegrass (Poa pratensis L.), and steep slopes $\left(>20^{\circ}\right)$ were dominated by rough fescue (Festuca scabrella Torr.). Kentucky bluegrass, rough fescue, bluebunch wheatgrass (Pseudoregnaria spicata [Pursh] A Love), and Idaho fescue (Festuca idahoensis Elmer) were dominant in the majority of areas in each pasture. During the 3-year study (1999 to 2001), standing crop of grasses averaged 1209 and $813 \mathrm{~kg} \cdot \mathrm{ha}^{-1}$ at the Thackeray Ranch and Ross Ranch, respectively. Grasses composed from $59 \%$ to $86 \%$ of the total herbaceous standing crop during most years. Areas of trees and shrubs were limited and only $1-5$ ha in size. Precipitation and temperatures were near normal in 1999, but in 2000 and 2001 temperatures in the summer were above normal and precipitation was below normal. The 15-year average precipitation at the study site is $410 \mathrm{~mm}$. During the summer (June through August), the average high temperature in nearby Havre is $28^{\circ} \mathrm{C}$, and the average low temperature is $10^{\circ} \mathrm{C}$.

During the study (1999 to 2001), cows were observed in 4 pastures at the Thackeray Ranch: Back East, Back West, Rakes East, and Rakes West (Table 1). At the Ross Ranch, cows grazed the Blackwood North and Blackwood South pastures during June and early July of 2000 and 2001 (Table 1). The pastures used to establish initial grazing patterns were larger than those used in the study, but had similar terrain and vegetation.

\section{Cattle}

Cows observed at the Thackeray Ranch in 1997 and 1998 varied from 3 to 9 years of age and were from Hereford and Tarentaise breeding (Bailey et al. 2001). These cows remained in the study during 1999 to 2001 except for animals that died or were sold (Table 2). Daughters of these cows that were sired by Angus, Charolais, Piedmontese, or Salers sires were also incorporated into the study as 3-year-olds during 1999 to 2001. Cows observed at the Ross Ranch in 1999 through 2001 were Herefords or Hereford and Angus crosses.

\section{Visual Observations}

At the Thackeray Ranch, locations of cows were recorded during the summers from 1997 to 2001 by horseback observers (Bailey et al. 2001). Cows were observed 2 to 4 times per week in 2 pastures during the summer grazing season. Topographic maps of each pasture were subdivided into 1- to 7-ha units based on slope, elevation, aspect, and distance to water. 
Observers were trained to recognize the boundaries of all subunits within each pasture. Two to 4 observers on horseback rode pastures during the early morning (0600 to 0900 hours) and attempted to record the location of every cow in the pasture. Observers rode close enough to each cow to observe her identification number from a plastic ear tag or a firebrand on the animal's hip (Thackeray Ranch) or shoulder (Ross Ranch). Observers recorded the pasture unit in which the animal was located. Ideally, scan samples should be instantaneous (Lehner 1979). However, individually identifying and observing 27 to 119 animals instantaneously on extensive foothill rangeland pastures was not feasible. Observers recorded about $87 \%$ of the animals in the herd during an observation period.

To describe the terrain use in a pasture, average slope and distance to water (horizontal and vertical) were calculated for each pasture subunit. For each cow, all location data collected in a pasture during a grazing season were pooled and used to determine the average slope, horizontal distance to water (HDW), and vertical distance to water (VDW) of observed cow locations in a pasture (Bailey et al. 2001).

\section{Assignment to Treatments}

Slope use and VDW of study cows were established during a 2year period before the study (1997 and 1998) at the Thackeray Ranch following the methods described in Bailey et al. (2001). These observations were ranked and then averaged to give one overall record of terrain use for each animal. At the Ross Ranch, cows were observed before the study in 1999. Slope use, HDW, and VDW were ranked and then averaged to give one record of terrain use for each animal. The mean of these terrain use rankings was used for assignment into 1 of 2 treatment groups. The hill climber group consisted of cows (top 50\%) that were observed on steeper slopes and at locations farther from water than the bottom dweller group of cows (bottom $50 \%$ ) that were observed on gentler slopes near water. Young cows (3 years of age) on the Thackeray Ranch that had not been evaluated in 1997 or 1998 were observed in at least 2 pastures (4 to 6 weeks per pasture) that were similar to, but separate from, study pastures. Terrain use for young cows was established separately from older cows. Young cows were assigned to the hill climber or bottom dweller groups based on these rankings with half of the animals placed in each group and then included in the study.

At the Thackeray Ranch, hill climber and bottom dweller groups grazed in similar but separate pastures during 1999, 2000, and 2001 (Table 2). During June and early July, hill climbers and bottom dwellers were randomly assigned to either the Rakes East or Rakes West pasture. During late July and August, hill climber and bottom dweller groups were randomly assigned to either the Back East or Back West pastures. At the Ross Ranch, hill climber and bottom dweller groups grazed the Blackwood North and Blackwood South pastures during June and early July. Random assignments of groups (treatments) to pastures on each ranch were made annually (Table 2).

\section{Global Positioning System (GPS) Locations}

Random samples of cows at the Thackeray Ranch were tracked using Lotek GPS 2000 collars (Lotek Wireless, Newmarket,
Table 2. Number of cows and timing of grazing for pastures within each ranch during the 3-year study.

\begin{tabular}{lllcc}
\hline & & & Bottom & Hill \\
Pasture within year & Ranch $^{1}$ & \multicolumn{1}{c}{ Season of grazing } & $\begin{array}{c}(n) \\
\text { dwimbers } \\
(n)\end{array}$ \\
\hline 1999 & & & & \\
Rakes East & Thackeray & June to mid-July & - & 75 \\
Rakes West & Thackeray & June to mid-July & 79 & - \\
Back East & Thackeray & Mid-July through August & 110 & - \\
Back West & Thackeray & Mid-July through August & - & 119 \\
2000 & & & & \\
Rakes East & Thackeray & June to mid-July & - & 39 \\
Rakes West & Thackeray & June to mid-July & 40 & - \\
Back East & Thackeray & Mid-July through August & - & 111 \\
Back West & Thackeray & Mid-July through August & 109 & - \\
Blackwood North & Ross & June to mid-July & - & 62 \\
Blackwood South & Ross & June to mid-July & 61 & - \\
2001 & & & & \\
Rakes East & Thackeray & June to mid-July & 29 & - \\
Rakes West & Thackeray & June to mid-July & - & 27 \\
Back East & Thackeray & Mid-July through August & - & 103 \\
Back West & Thackeray & Mid-July through August & 99 & - \\
Blackwood North & Ross & June to mid-July & 65 & - \\
Blackwood South & Ross & June to mid-July & - & 63 \\
\hline
\end{tabular}

${ }^{1}$ Cattle at the Thackeray Ranch that grazed in Rakes East or Rakes West pastures were included in the cattle that grazed the Back East or Back West pastures.

Ontario). These collars contain GPS receivers, which recorded cow locations with an expected accuracy of $\pm 7 \mathrm{~m}$ after differential correction (Moen et al. 1997). Five to 7 cows in each treatment group (hill climbers and bottom dwellers) were collared per period. In 1999 and 2000, collars were placed on randomly selected cows during 3 periods ( 2 weeks in length) in each pasture, and data were recorded every 15 minutes for 3 to 10 consecutive days depending on battery life. Cows in Texas and Colorado were seldom found in the same section of a pasture at 0700 hours for more than 2 consecutive days (Bailey et al. 1990), and cows in Montana were never in the same visual zone for more than 4 consecutive days at 0700 hours (Bailey et al. 2004). Thus, increasing the number of days that a cow is tracked may better quantify the actual terrain use of the cow. In 2001, locations of randomly selected cows were recorded every 10 minutes for 10 to 15 consecutive days during first half and second half of grazing in each pasture. Difference between 2001 and 1999 or 2000 was because of technological advancements in batteries that allowed collars to track for an additional 5 days in 2001. Cows at the Ross Ranch were not observed via GPS collars, because there were not enough collars to track cows at both sites.

Slope, HDW, and elevation of the geographical coordinates recorded by the collars were obtained from a digital elevation model of the study pastures (US Geological Survey, Sioux Falls, $\mathrm{SD})$. Fence boundaries and watering locations were recorded using an 8-channel, L-band GPS receiver with $\pm 1 \mathrm{~m}$ positional accuracy (Omnistar, Houston, TX). Mean slope use, HDW, and elevation of collared cows were calculated individually from all positions recorded during a period. 


\section{Forage Utilization}

Forage utilization and stubble heights collected throughout the pastures were analyzed to determine if uniformity of grazing differed between treatments. A total of 1127 forage utilization measurements (transects) were evaluated. In each pasture, 1 or 2 transects were randomly placed within each of the subunits used for visual observations. Larger subunits had 2 transects. Fifteen plants were measured at 2-m intervals along each transect using the height-weight procedure described by Cook and Stubbendieck (1986). Height-weight curves were developed for major species (Kentucky bluegrass and rough fescue). Published relationships (US Forest Service 1980) were used for other grasses. Forage utilization was calculated from stubble heights using these height-weight curves.

\section{Statistical Analyses}

Originally, the statistical design for this study was a paired $t$ test where hill climbers and bottom dwellers were evaluated in sets of 2 similar pastures. However, we were unable to identify or develop sufficiently similar sets of pastures in the foothill rangeland of the Bear's Paw Mountains. Thus, we changed the design so that treatment (bottom dwellers or hill climbers) was randomly assigned to pastures (within a set) each year, and both treatments were assigned to a pasture at least once. Pastures were used as blocks in the statistical design. The pasture by treatment interaction was the error term to test for differences between hill climber and bottom dweller treatments when evaluating horseback observation data and the GPS tracking collar data. The design was unbalanced, because treatments were not applied to pastures at the Thackeray Ranch the same number of times. These data were analyzed using a mixedmodel analysis (Littell et al. 1996), which more accurately accounts for unbalanced data. Separate analyses using a fixed model (SAS Institute 1999) were also evaluated after removing data from 1999, which allowed the design to be balanced. Results from the fixed model using balanced data were similar to those from the mixed model using all the data (unbalanced). We chose to present the results from all of the data to better represent the experiment as it was conducted and provide more replication.

Location data obtained from visual observations were analyzed with 4 dependent variables characterizing average terrain use (mean observed slope, HDW, VDW, and visual terrain index [VTI]). The VTI was calculated by cow for each pasture within year. The formula for calculating the VTI was the following:

$$
V T I=\frac{\text { slope }_{i} / \text { slope }_{j}+H D W_{i} / H D W_{j}+V D W_{i} / V D W_{j}}{3} \cdot 100
$$

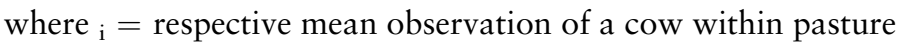
and year, and ${ }_{j}=$ respective mean observation of all cows within all pastures and years. The VTI is essentially an average of 3 terrain attributes using normalized values. It was developed to compare treatments using a combination of terrain use attributes. The statistical model used to evaluate these dependent variables consisted of pasture, treatment (hill climber or bottom dweller), and year as fixed effects and the pastureby-treatment interaction within year as a random effect. The pasture-by-treatment interaction within year was used as the error term for testing for differences between treatments. The degrees of freedom were calculated using the Kenward-Roger approach of PROC MIXED (Littell et al. 1996) and denominator degrees of freedom for the F-test for testing for differences in treatments varied from 6.6 to 7.2 with the 4 dependent variables.

Location data obtained from GPS collars were analyzed similarly to the visual location data. Four dependent variables characterized terrain use (mean slope, HDW, elevation, and the GPS terrain index [GTI]). The GTI was calculated by cow for each pasture within year at the Thackeray Ranch. The formula for calculating GTI was as follows:

\section{GTI}

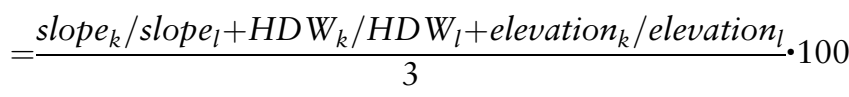

where $_{\mathrm{k}}=$ respective mean observation of collared cows within pasture and year, and ${ }_{1}=$ respective mean observation of all collared cows within all pastures and years.

The GTI was also developed to compare treatments using an average of multiple terrain use attributes that were normalized. Collar data in 2001 were modified by removing the last 5 days from the first period and the first 5 days from the second period. The two 5-day segments were then combined to create a 10-day period. This modification allowed for three 10-day periods similar to that of the previous 2 years. Two analyses were conducted. The first analysis removed the middle period in 1999 and 2000, and the second analysis was conducted on the modified data set. Conclusions drawn from both analyses were not different. Therefore, the data presented contain modified 2001 data, with 3 periods. For the GPS collar data, the model included pasture, treatment, year, period (first 2 weeks, middle 2 weeks, or the last 2 weeks of grazing in each pasture), cow age ( 3 to 4, 5 to 6 , and 7+ years old), treatment-by-period interaction, and treatment-by-cow age interaction as fixed effects and the treatment-by-period interaction with year as a random effect. The pasture-by-treatment interaction within year was used as the error term to test for treatment differences. The denominator degrees of freedom (Kenward-Roger approach; Littell et al. 1996) used in the F-test for treatment varied from 4.0 to 4.9 with the 4 dependent variables.

Forage utilization and stubble heights collected throughout the pastures were analyzed to determine if uniformity of grazing differed between treatments. The statistical model included year and pasture as fixed effects to adjust forage utilization values collected annually in each pasture to a common value. Treatment was included as a fixed effect to determine if there were differences in the linear relationships (regression coefficients) between forage utilization and terrain attributes (slope, HDW, and VDW). Continuous effects in the model included terrain attributes and interaction between treatment and terrain attributes. Important interactions between treatment and the continuous variables (terrain attributes) would suggest that the relationship between forage use and terrain (e.g., slope) varied between treatments.

Forage utilization and stubble heights in riparian areas and coulee bottoms were analyzed separately. Coulee bottoms often contained ephemeral streams. These areas were identified before the study and were areas that received heavy use (greater 
Table 3. Least squares means \pm SE of terrain use for hill climber and bottom dweller cows observed by horseback riders (visual locations) and recorded by global positioning system (GPS) tracking collars (GPS locations).

\begin{tabular}{|c|c|c|c|}
\hline Variable & Hill climber & Bottom dweller & $P$ value \\
\hline \multicolumn{4}{|l|}{ Visual locations } \\
\hline Slope, degrees & $9.7 \pm 0.3$ & $9.3 \pm 0.3$ & 0.32 \\
\hline Horizontal distance to water, $\mathrm{m}$ & $588 \pm 26$ & $547 \pm 26$ & 0.31 \\
\hline Vertical distance to water, m & $48.1 \pm 1.9$ & $42.5 \pm 1.9$ & 0.07 \\
\hline Visual terrain index ${ }^{1}$ & $96.4 \pm 2.4$ & $89.0 \pm 2.4$ & 0.06 \\
\hline Observations $(n)$ & 601 & 590 & - \\
\hline \multicolumn{4}{|l|}{ Error term $\mathrm{df}=6.6$ to 7.2} \\
\hline \multicolumn{4}{|l|}{ GPS locations } \\
\hline Slope, degrees & $10.2 \pm 0.2$ & $9.8 \pm 0.2$ & 0.16 \\
\hline Horizontal distance to water, $\mathrm{m}$ & $487 \pm 30$ & $443 \pm 30$ & 0.36 \\
\hline Elevation, $\mathrm{m}$ & $1236 \pm 2$ & $1232 \pm 2$ & 0.29 \\
\hline GPS terrain index ${ }^{2}$ & $102.2 \pm 2.3$ & $97.6 \pm 2.3$ & 0.23 \\
\hline Observations $(n)$ & 105 & 108 & - \\
\hline \multicolumn{4}{|l|}{ Error term $\mathrm{df}=4.0$ to 4.9} \\
\hline \multicolumn{4}{|c|}{$\begin{array}{l}{ }^{1} \text { Visual terrain index }=\left(\left(\text { slope }_{k} / \mathrm{slope}_{1}+\mathrm{HDW}_{\mathrm{k}} / \mathrm{HDW}_{1}+\mathrm{VDW}_{\mathrm{k}} / \mathrm{NDW}_{\mathrm{l}}\right) / 3\right) \cdot 100 \text {, where } \\
\mathrm{k}=\text { respective mean observation of observed cows within pasture and year; } ;=\text { respective } \\
\text { mean observation of all observed cows within all pastures and years; HDW is the horizontal } \\
\text { distance to water; and VDW is the vertical distance to water. }\end{array}$} \\
\hline \multicolumn{4}{|c|}{ 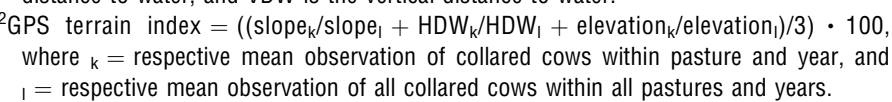 } \\
\hline
\end{tabular}

than $60 \%$ utilization) before the study based on height-weight utilization monitoring at the Thackeray Ranch in 1997 and 1998 and at the Ross Ranch in 1999. Average forage utilization and stubble height were calculated annually in each pasture. The statistical model included pasture, treatment, and year as fixed effects, and the pasture-by-treatment interaction within year as a random effect. Analyses using a paired $t$ test for these data were also conducted and are presented.

\section{RESULTS AND DISCUSSION}

\section{Visual Observations}

Hill climber and bottom dweller cows were observed on similar slopes $(P=0.32)$ and at similar horizontal distances from water $(P=0.31)$. Hill climbers traveled farther $(P=0.07)$ vertically from water $(48.1 \mathrm{~m})$ than did bottom dwellers (42.5 $\mathrm{m})$. Because the analyses were based on differences between pastures $(n=8)$ and not differences between animals, it is not surprising that statistical differences between treatment means were difficult to detect. In addition, the relative importance of the 3 indicators of terrain use appeared to vary among pastures. For example, HDW was not as important in the Rakes East and Rakes West pastures because they were smaller than the other pastures. Thus, a VTI was developed to combine and pool the differences in observed terrain use (Table 3 ). The VTI was greater $(P=0.06)$ for hill climbers $(96.4)$ than for bottom dwellers (89.0). The VTI indicates that horseback observers found hill climbers on terrain that was steeper and farther from water horizontally and vertically than bottom dwellers when the 3 indicators of terrain use were combined.
Table 4. Least squares means \pm SE of terrain use for age classification of cows tracked with global positioning system (GPS) collars.

\begin{tabular}{|c|c|c|c|c|}
\hline \multirow[b]{2}{*}{ Variable } & \multicolumn{3}{|c|}{ Age } & \multirow[b]{2}{*}{$P$ value } \\
\hline & $3-4$ years & $5-6$ years & $\geq 7$ years & \\
\hline Slope, degrees & $9.6 \pm 0.2^{y}$ & $10.1 \pm 0.2^{z}$ & $10.3 \pm 0.1^{z}$ & $<0.01$ \\
\hline \multicolumn{5}{|l|}{ Horizontal distance } \\
\hline to water, m & $424 \pm 27$ & $483 \pm 25$ & $489 \pm 24$ & 0.06 \\
\hline Elevation, m & $1233 \pm 2$ & $1234 \pm 2$ & $1234 \pm 2$ & 0.92 \\
\hline GPS terrain index ${ }^{1}$ & $95.5 \pm 2.0^{y}$ & $101.6 \pm 1.9^{z}$ & $102.6 \pm 1.8^{z}$ & $<0.01$ \\
\hline Observations $(n)$ & 65 & 62 & 86 & - \\
\hline
\end{tabular}

${ }^{1}$ GPS terrain index $=\left(\left(\right.\right.$ slope $_{k} /$ slope $_{1}+\mathrm{HDW}_{\mathrm{k}} / \mathrm{HDW}_{1}+$ elevation $_{\mathrm{k}} /$ elevation $\left.\left._{\mathrm{l}}\right) / 3\right) \cdot 100$, where ${ }_{k}=$ respective mean observation of collared cows within pasture and year; $\mathrm{I}=$ respective mean observation of all collared cows within all pastures and years; and HDW is the horizontal distance to water.

$y, z$ Least squares means $\pm S E$ within the same row without common superscripts differ $(P<0.05)$.

\section{GPS Tracking}

Cow Age. Slope use varied among the 3 age classes of cows $(P<0.01)$. Younger cows $(3-4$ years of age $)$ were observed on gentler $(P<0.05)$ slopes $\left(9.6^{\circ}\right)$ than cows of 5 to 6 years of age and $\geq 7$ years of age $\left(10.1^{\circ}\right.$ and $10.3^{\circ}$, respectively). Cow age tended to be a factor $(P=0.06)$ for HDW (Table 4$)$, but there were no differences among cow age classes for elevation $(P=0.92)$. The GTI varied $(P<0.01)$ among cow age classes (Table 4), with younger animals using less rugged terrain. In Oregon, Morrison (2002) found that younger cows spent more time near water than did older cows. Managers may consider excluding younger cows from rugged rangeland or areas with sensitive riparian areas during late summer when cattle typically spend more time in riparian zones (Parsons et al. 2003).

Extent of Grazing. Cows were observed on steeper $(P<0.01)$ slopes as grazing within a pasture progressed (Table $5)$. During the first 2 weeks (early grazing period) in a pasture, cows were observed closer $(P<0.01)$ horizontally to water $(413 \mathrm{~m})$ than they were during the middle $(500 \mathrm{~m})$ or late $(423$ $\mathrm{m})$ periods. Cows were observed at similar $(P>0.05) \mathrm{HDW}$ in the last 4 weeks in a pasture (middle and late periods). Cows were observed at lower $(P<0.05)$ elevations in the early

Table 5. Least squares means \pm SE of terrain use by grazing period of cows observed by global positioning system (GPS) collars.

\begin{tabular}{|c|c|c|c|c|}
\hline \multirow[b]{2}{*}{ Variable } & \multicolumn{3}{|c|}{$\begin{array}{l}\text { Grazing periods within a pasture } \\
\text { ( } 2 \text { weeks per period) }\end{array}$} & \multirow[b]{2}{*}{$P$ value } \\
\hline & Early & Middle & Late & \\
\hline Slope, degrees & $9.3 \pm 0.1^{x}$ & $10.0 \pm 0.1^{y}$ & $10.7 \pm 0.1^{z}$ & $<0.01$ \\
\hline \multicolumn{5}{|l|}{ Horizontal distance } \\
\hline to water, m & $413 \pm 24^{y}$ & $500 \pm 24^{z}$ & $482 \pm 25^{z}$ & $<0.01$ \\
\hline Elevation, m & $1230 \pm 2^{y}$ & $1233 \pm 2^{\mathrm{yz}}$ & $1240 \pm 2^{z}$ & $<0.01$ \\
\hline GPS terrain index ${ }^{1}$ & $93.7 \pm 1.8^{y}$ & $102.4 \pm 1.8^{z}$ & $103.6 \pm 1.9^{z}$ & $<0.01$ \\
\hline Observations $(n)$ & 67 & 86 & 60 & - \\
\hline \multicolumn{5}{|c|}{$\begin{array}{l}{ }^{1} \text { GPS terrain index }=\left(\left(\text { slope }_{k} / \text { slope }_{1}+\mathrm{HDW}_{\mathrm{k}} / \mathrm{HDW}_{1}+\text { elevation }_{\mathrm{k}} / \text { elevation }_{\mathrm{l}}\right) / 3\right) \cdot 100 \text {, } \\
\text { where }{ }_{\mathrm{k}}=\text { respective mean observation of collared cows within pasture and year; } \\
\mathrm{I}=\text { respective mean observation of all collared cows within all pastures and years; and } \\
\text { HDW is the horizontal distance from water. }\end{array}$} \\
\hline $\begin{array}{l}\mathrm{x}, \mathrm{y}, \mathrm{z} \text { Least squares mea } \\
(P<0.05)\end{array}$ & \pm SE within the & same row without & rommen suners & \\
\hline
\end{tabular}



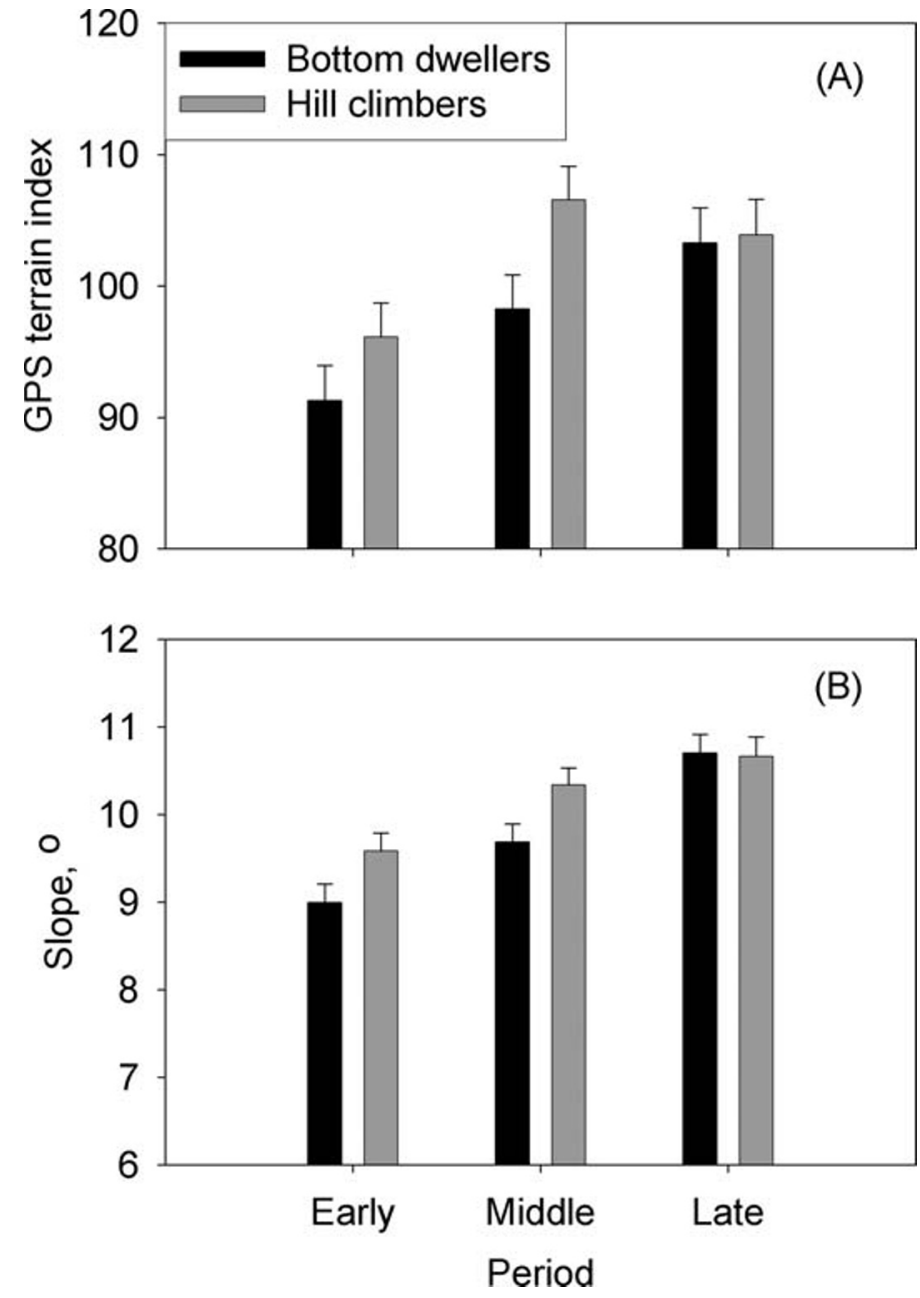

Figure 1. The interaction of treatment by period for the global positioning system (GPS) terrain index (A) and slope (B). Least-squares means \pm SE are given for treatments (hill climber vs. bottom dweller) during the 32 -week periods within the 6 weeks that pastures were grazed (early, middle, and late). The $P$ values for the interaction of treatment and period were 0.04 for the GPS terrain index and 0.09 for slope.

period than in the late period (Table 5). The GTI was least $(P<0.01)$ in the first period $(93.7)$ and increased in the middle (102.4) and late (103.6) periods.

Treatment Differences. Hill climber and bottom dweller cows were observed on similar $(P=0.16)$ slopes and at similar $(P>0.20)$ elevations and horizontal distances from water (Table 3). The GTI was similar $(P=0.23)$ for bottom dwellers and hill climbers. Treatment did not interact with cow age for any measure of terrain use $(P>0.20)$.

The GPS tracking data represent terrain use on a 24-hour basis. In an earlier study at this location (Bailey et al. 2004), both hill climber and bottom dweller cows spent 8 to 9 hours near water (within $100 \mathrm{~m}$ ) during midday (0930 to 1830 hours). During midday (over one-third of the observations), terrain use of all cows was similar.

Elevation may not be as good of an indicator of terrain use as VDW in foothill rangeland. Cattle that climb over a ridge and down the other side could potentially graze similar elevations as animals that did not climb over a ridge and incurred substantially less effort traveling to a feeding site.
VDW accounts for the climb required get over a ridge and the climb to cross the ridge a second time on the trip back to water (Bailey et al. 2001). For the GPS tracking data, it was impractical to calculate VDW, and elevation was used instead.

The evaluation of the interaction between treatment and period $(P=0.04)$ for the GTI suggested that hill climber cows used rougher terrain than bottom dwellers during the first and second 2-week periods, but terrain use was similar during the last 2 weeks of grazing in a pasture (Fig. 1A). The interaction between treatment and period for slope use $(P=0.09)$ suggests that hill climbers spent more time on steep slopes than did bottom dwellers during the first 2 weeks a pasture was grazed, but during the later 4 weeks there was no difference in slope use (Fig. 1B). There was no interaction between treatment and period for elevation $(P=0.75)$ and HDW $(P=0.18)$. To further evaluate these interactions, we used our mixed statistical model without period or the period-by-treatment interaction, using only the data from a single period so that we could compare treatments, using the treatment-by-pasture interaction within year as the error term. During the first 2 weeks of grazing in a pasture, the GTI differed $(P=0.09)$ between hill climbers $(95.4 \pm 1.5$, mean \pm SE) and bottom dwellers $(91.1 \pm 1.6)$, and slope use differed $(P=0.07)$ between hill climbers $\left(9.0^{\circ} \pm 0.2^{\circ}\right)$ and bottom dwellers $\left(9.6^{\circ} \pm 0.2^{\circ}\right)$. During the second 2 -week period, GTI varied $(P=0.08)$ between hill climbers (108.1 \pm 3.4$)$ and bottom dwellers $(96.8 \pm 3.6)$, but slope use was similar $(P=0.22)$ for both treatments. Hill climbers and bottom dwellers used similar terrain (GTI and slope) during the last 2 weeks in the pastures $(P>0.20)$.

Apparently, grazing patterns of hill climbers and bottom dwellers differ most when animals are first released in a pasture. Hill climbers are more willing to graze steep slopes soon after entering a pasture, whereas bottom dwellers apparently avoid rugged areas far from water until the forage on gentle terrain near water is depleted.

\section{Utilization}

Hill climbers utilized forages to a greater $(P=0.02)$ extent on steeper slopes than did bottom dweller cows (Table 6) when HDW and VDW were included in the model. For every degree increase in slope, forage utilization declined by 0.29 percentage points more in pastures grazed by bottom dweller cows than in pastures grazed by hill climber cows. Hill climbers utilized forages at greater $(P=0.003)$ distances from water than did bottom dwelling cows. For every $100 \mathrm{~m}$ farther horizontally from water, forage utilization was 0.9 percentage points less in pastures grazed by bottom dweller cows than in pastures grazed by hill climber cows. There was no interaction between treatment and VDW $(P=0.21)$. This study further supports the observations of Cook (1966) and Mueggler (1965) that cattle avoid steep slopes and areas far from water. Terrain attributes (slope, HDW, and VDW) were all negatively correlated to forage utilization. The interesting aspect of our analysis is the interactions of terrain attributes by treatment. For terrain slope and HDW, the slope of the regression lines for hill climber cows is less steep than the slope of the regression line for bottom dweller cows. A regression of forage utilization on terrain slope or HDW with a slope of zero would indicate uniform grazing. Thus, hill climber cows grazed the pastures more uniformly than did bottom dweller cows. 
Table 6. Mean squares and least-square constants from analyses of representing the sources of variation used to explain differences in forage utilization.

\begin{tabular}{lcccc}
\hline Effect & df & MS & $P$ value & Constant \\
\hline Pasture & 5 & 30011 & $<0.01$ & - \\
Year & 2 & 8935 & $<0.01$ & - \\
Treatment & 1 & 2004 & $<0.01$ & - \\
$\quad$ Slope, degrees & 1 & 83163 & $<0.01$ & $-0.973 \pm 0.091$ \\
$\quad$ Vertical distance to & & & & \\
$\quad$ water (VDW), m & 1 & 31364 & $<0.01$ & $-0.227 \pm 0.025$ \\
Horizontal distance to & & & & \\
$\quad$ water (HDW), m & 1 & 12313 & $<0.01$ & $-0.007 \pm 0.002$ \\
Slope by treatment, & & & & - \\
$\quad$ degrees & 1 & 1436 & 0.02 & - \\
$\quad$ Bottom dweller & - & - & - & $-0.292 \pm 0.125$ \\
$\quad$ Hill climber & - & - & - & 0 \\
HDW by treatment, $\mathrm{m}$ & 1 & 2359 & $<0.01$ & - \\
$\quad$ Bottom dweller & - & - & - & $-0.009 \pm 0.003$ \\
$\quad$ Hill climber & - & - & - & 0 \\
VDW by treatment, $\mathrm{m}$ & 1 & 42 & 0.21 & - \\
$\quad$ Bottom dweller & - & - & - & $0.045 \pm 0.036$ \\
$\quad$ Hill climber & - & - & - & 0 \\
Error & 1112 & 263 & - & - \\
\hline
\end{tabular}

\section{Utilization and Stubble Heights in Riparian Areas and Coulee Bottoms}

Bottom dweller cows utilized a greater $(P=0.06)$ amount of forage in riparian areas and coulee bottoms than did hill climber cows $(62.4 \%$ and $48.4 \%$, respectively). Stubble heights were taller $(P=0.01)$ in riparian areas and coulee bottoms of the pastures grazed by hill climber cows $(13.3 \mathrm{~cm})$ than in areas grazed by bottom dweller cows $(8.1 \mathrm{~cm}$; Table 7$)$. Results from the paired $t$ test analyses were similar to those evaluated with the mixed model. Stubble heights near ephemeral and perennial streams were taller $(P<0.01)$ and utilization values were lower $(P<0.01)$ in pastures grazed by hill climbers than in those grazed by bottom dwellers.

The differences in stubble height observed between treatments in this study would be economically important for many public land ranchers. A standard for grazing on riparian areas is often forage stubble height of 10 to $13 \mathrm{~cm}$ (Chaney et al. 1993; Hall and Bryant 1995). If stubble heights fall below the standard, livestock are often required to be moved to a new pasture or off the allotment. In this study, pastures grazed by hill climbers had acceptable grazing levels based on this standard, whereas grazing levels in pastures grazed by bottom dwellers would not be acceptable.

\section{Potential of Selection to Modify Grazing Distribution}

For individual animal selection to be effective, terrain use must be a repeatable trait, and there must be variation among individuals (Bailey 1999). Roath and Krueger (1982) found that cattle occupy the same home range area year to year, and suggested that removing groups of cattle grazing sensitive areas could change overall grazing patterns without altering other groups. Furthermore, Hunter and Milner (1963) found hill sheep return to their home range within 2.5 hours following morning herding. A cross-fostering experiment showed that
Table 7. Least-squares means \pm SE of stubble heights and forage utilization observed in riparian areas and coulee bottoms in pastures grazed by hill climber and bottom dweller cows.

\begin{tabular}{lccc}
\hline Variable & Hill climber & Bottom dweller & $P$ value \\
\hline Stubble height, $\mathrm{cm}$ & $13.3 \pm 1.2$ & $8.1 \pm 1.2$ & 0.01 \\
Forage utilization, $\%$ & $48.4 \pm 5.0$ & $62.4 \pm 5.0$ & 0.07 \\
Observations $(n)$ & 8 & 8 & - \\
Error df $=12$ & - & - & - \\
\hline
\end{tabular}

cows grazed the same home ranges in which they were reared as calves (Howery et al. 1998). Hunter and Milner (1963) and Lawrence (1990) also found matrilineally related sheep tend to graze similar parts of the pasture. This suggests that selecting animals with desirable grazing patterns might improve livestock distribution. In contrast, Mosley (1999) suggests that social dominance hierarchy of the herd may be the primary influence on terrain use. Mosley was concerned that removing animals with undesirable patterns would not be effective. Other animals would "fill in the vacuum." Hunter (1960) found in a study using Cheviot Hill sheep that adding animals to a pasture containing sheep with established territories results in a disproportional distribution of new animals to territory categorized as the poorest. The previous research raised a critical question: Will the differences between individual grazing patterns observed in common pastures continue when the animals are separated?

Multiple measurements were made to evaluate the potential of selection to alter the terrain use of cattle. Two different methods of observing cattle locations resulted in very similar findings. Using a normalized average of terrain use attributes (VTI), locations of cattle recorded by horseback observers demonstrated that hill climber cows used steeper slopes and/or areas farther horizontally and vertically from water. Tracking data recorded by GPS collars also showed that hill climbers used more rugged terrain during the first 2 to 4 weeks of the 6 weeks that pastures were grazed. The greatest difference in terrain use between treatments occurred with the normalized averages of terrain attributes (VTI and GTI). Cook (1966) identified slope as an important determinant of forage utilization, but slope alone is not adequate to evaluate the utilization of forage on mountainous terrain. He identified 11 significant factors affecting forage utilization, and stated that "no one factor could be used as a reliable index to predict use." The indices used in this study allowed us to equally integrate slope, HDW, and elevation (VDW) into 1 value, which may be more reflective of overall terrain use, especially when evaluated in multiple pastures. Furthermore, forage utilization data also suggest hill climbers grazed more uniformly than bottom dwellers. Utilization was greater on steeper slopes and areas farther horizontally from water when grazed by cows classified as hill climbers from preliminary observations. Lastly, bottom dweller cows utilized forage to a greater extent in riparian areas and coulee bottoms resulting in shorter stubble heights than in areas grazed by hill climber cows.

\section{MANAGEMENT IMPLICATIONS}

This research clearly demonstrates that individual animal selection has the potential to improve grazing distribution 
patterns. Differences in individual grazing patterns observed in common pastures persisted even after animals were separated. Cows that were previously observed on steeper slopes and areas farther horizontally and vertically from water (hill climbers) continued to use steeper and higher terrain and areas farther from water than cows that were previously observed in gentler slopes near water (bottom dwellers). Terrain use of hill climber and bottom dweller cows was not only different statistically; treatments differed when compared to a common public land management standard for riparian areas.

Although the results reported here are favorable, evaluations using a wider array of pasture types and locations and other cattle herds are needed before individual animal selection can be widely applied to improve uniformity of grazing. First, the selection pressure simulated in this study was high, because the herd was ranked and then split in half. Selection strategies based on culling (typically $10 \%$ to $20 \%$ of the herd are removed each year) would result in less selection pressure. Genetic progress from culling alone, without sire selection, is slow even when heritability is relatively high (Falconer 1960). Second, the relative contributions of genotype and early learning on terrain use patterns of cattle must be determined. If terrain use is reasonably heritable, grazing patterns can be modified by sire and family selection. If early learning is important (Howery et al. 1998), terrain use could be modified by management and training when replacement animals are calves. Continued evaluation of individual animal selection as a tool for modifying cattle grazing patterns in rugged and extensive rangelands appears justified.

\section{LITERATURE CITED}

Bailey, D. W. 1999. Influence of species, breed and type of animal on habitat selection. In: K. L. Launchbaugh, K. D. Sanders, and J. C. Mosley [EDS.]. Grazing behavior of livestock and wildlife. Moscow, ID: University of Idaho. Idaho Forest, Wildlife and Range Experiment Station Bulletin \#70. p 101-108.

Balley, D. W. 2004. Management strategies for optimal grazing distribution and use of arid rangelands. Journal of Animal Science 82:E147-E153.

Bailey, D. W., B. Dumont, and M. F. WallisDeVries. 1998. Utilization of heterogeneous grasslands by domestic herbivores: theory to management. Annales de Zootechnie 47:321-333.

Bailey, D. W., J. E. Gross, E. A. Laca, L. R. Rittenhouse, M. B. Coughenour, D. M. Swift, AND P. L. SIms. 1996. Invited synthesis paper: mechanisms that result in large herbivore grazing distribution patterns. Journal of Range Management 49:386-400.

Balley, D. W., M. R. KelL, And L. R. Rittenhouse. 2004. Research observation: daily movement patterns of hill climbing and bottom dwelling cows. Journal of Range Management 57:20-28.

Balley, D. W., D. D. Kress, D. C. Anderson, D. L. Boss, and E. T. Miller. 2001. Relationship between terrain use and performance of beef cows grazing foothill rangeland. Journal of Animal Science 79:1883-1891.

Bailey, D. W., J. W. Walker, and L. R. Rittenhouse. 1990. Sequential analysis of cattle location: day to day movement patterns. Applied Animal Behaviour Science 25:137-148.

BlaCKBURN, W. H. 1984. Impacts of grazing intensity and specialized grazing systems on watershed characteristics and responses. In: Developing strategies for rangeland management. Boulder, CO: Natural Resources Council/ National Academy of Science, Westview Press. p 927-933.

Chaney, E., W. Elmore, and W. S. Platts. 1993. Managing change: Livestock grazing on western riparian areas. Eagle, ID: EPA Publication, Northwest Resource Information Center. $31 \mathrm{p}$.
Cook, C. 1966. Factors affecting utilization of mountain slopes by cattle. Journal of Range Management 19:200-204.

Cook, C. W., AND J. StuBbendieCK. 1986. Range research: Basic problems and techniques. Denver, C0: Society for Range Management. $317 \mathrm{p}$.

DelCurto, T., M. Porath, M. Mclnnis, P. Momont, and C. Parsons. 1999. Management strategies for optimal beef cattle distribution and use of mountain riparian meadows. In: K. L. Launchbaugh, K. D. Sanders, and J. C. Mosley [EDS.]. Grazing behavior of livestock and wildlife. Moscow, ID: University of Idaho. Idaho Forest, Wildlife and Range Experiment Station Bulletin \#70. p 119-129.

FalConeR, D. S. 1960. Introduction to quantitative genetics. New York, NY: Ronald Press. $365 \mathrm{p}$.

Hall, F. C., and L. Bryant. 1995. Herbaceous stubble height as a warning of impending cattle grazing damage to riparian areas. Portland, OR: US Department of Agriculture, Forest Service, Pacific Northwest Research Station. General Technical Report PNW-GTR-362. 9 p.

Howery, L. D., F. D. Provenza, and R. E. Banner. 1998. Social and environmental factors influence cattle distribution. Applied Animal Behaviour Science 55: 231-244.

Howery, L. D., F. D. Provenza, R. E. Banner, and C. B. Scott. 1996. Differences in home range and habitat use among individuals in a cattle herd. Applied Animal Behaviour Science 49:305-320.

Hunter, R. F. 1960. Aims and methods in grazing-behaviour studies on hill pastures. Proceedings of the International Grassland Congress 8:454-457.

Hunter, R. F., AND C. MiLner. 1963. The behavior of individual related and groups of South Country Cheviot Hill Sheep. Animal Behaviour 11:507-513.

Kauffman, J. B., W. C. Krueger, and M. Vavra. 1983. Impacts of cattle grazing streambanks in northeastern Oregon. Journal of Range Management 36: 683-685.

LaWRenCE, A. B. 1990. Mother-daughter and peer relationships of Scottish hill sheep. Animal Behaviour 39:481-486.

LeHNeR, P. N. 1979. Handbook of ethological methods. New York, NY: Garland STMP Press. 403 p.

Littell, R. C., G. A. Milliken, W. W. Stroup, and R. D. Wolfinger. 1996. SAS system for mixed models. Cary, NC: SAS Institute. 633 p.

Moen, R., J. PAStoR, ANd Y. Cohen. 1997. Accuracy of GPS telemetry collar locations with differential correction. Journal of Wildlife Management 61:530-539.

Morrison, J. A. 2002. The influence of cow age on grazing distribution and utilization of mountain riparian areas and adjacent uplands [thesis]. Corvallis, OR: Oregon State University. $101 \mathrm{p}$.

Mosley, J. C. 1999. Influence of social dominance on habitat selection by freeranging ungulates. In: K. L. Launchbaugh, K. D. Sanders, and J. C. Mosley [EDS.]. Grazing behavior of livestock and wildlife. Moscow, ID: University of Idaho. Idaho Forest, Wildlife and Range Experiment Station Bulletin \#70. p 109-118.

MueggleR, W. F. 1965. Cattle distribution on steep slopes. Journal of Range Management 18:255-257.

Parsons, C. T., P. A. Momont, T. DelCurto, M. Mclnnis, and M. L. Porath. 2003. Cattle distribution patterns and vegetation use in mountain riparian areas. Journal of Range Management 56:334-341.

Pinchak, W. E., M. A. Smith, R. H. Hart, and J. W. Waggoner, JR. 1991. Beef cattle grazing distribution patterns of foothill rangeland. Journal of Range Management 44:267-275.

Roath, L. R., and W. C. Krueger. 1982. Cattle grazing and behavior on a forested range. Journal of Range Management 35:332-338.

SAS Institute. 1999. SAS/STAT user's guide. Version 8. Cary, NC: SAS Institute. $3884 \mathrm{p}$.

Smith, M. A., J. D. Rodgers, J. L. Dodd, And Q. D. Skinner. 1992. Declining forage availability effects on utilization and community selection by cattle. Journal of Range Management 45:391-395.

US Forest Service. 1980. Utilization gauge: An instrument for measuring the utilization of grasses. Wheaton, IL: American Slide-Chart Corporation. Rocky Mountain Forest and Range Experiment Station Publication. 